\title{
Impact Analysis of Oversize Cylinder Liner on Piston Ring and Surging for Main Engine
}

\author{
Agus Tjahjono, Vega Fonsula Andromeda, Purwantono, and Afdolludin Afta Tazani
}

\begin{abstract}
Cylindrical liner is the place of burning to generate power or effort inside the Mother Machine. The size of the oversized diameter will affect the incomplete combustion. The purpose of this study was to determine the causes of broken piston rings and surging, the impact of oversized liners and strategies to minimize the impact of oversized cylinder liners. The research method used is SWOT analysis and questionnaire method distributed to 51 samples of students officer of ATT II class and on board interview. Oversized cylinder liner causes the piston ring to be broken and incomplete combustion causing surging turbocharger. Strategies to minimize the impact of oversized liner by replacing piston rings and cylinder liner, cleaning scavenging of water thrunk and piston groove for normal rinse air pressure and combustion quality increases
\end{abstract}

Index Terms - cylinder liner, piston ring, SWOT.

\section{INTRODUCTION}

$\mathbf{T}$ here are three main elements when optimizing the performance of Internal Combustion (IC) engines in terms of improved energy efficiency [1]. First, it is important to reduce the thermal loss, which accounts for $50-60 \%$ of all losses. Second, friction losses on piston-cylinder systems, valves and engine bearings represent $15-20 \%$ of all gross losses. Almost $45 \%$ of these losses can be attributed to the cylinder system, $30-45 \%$ of which are caused by the piston ring. The oversized cylinder liner exceeds the maximum tolerance limit leading to compression and burnout escape. So much dirt that come burn and clog the groove so that piston ring jam and broken. Incomplete combustion causes unstable flue gas so turbocharger rotation goes up and surges. This study aims to analyze strategies to minimize the impact of oversized cylinder liner of Main Engine.

\section{Place AND Time of Research}

The study was conducted for more than twelve months starting from December $13^{\text {rd }}, 2015$ to January $4^{\text {th }}, 2017$. The study was

A.Tjahjono is with the Engineering Department, Politeknik Ilmu Pelayaran Semarang, 50242, Semarang, Central Java, Indonesia (e-mail: a_agus_tjahjono70@yahoo.co.id)

V.F. Andromeda is with the Nautical Department, Politeknik Ilmu Pelayaran Semarang, 50242, Semarang, Central Java, Indonesia

Purwantono is with the Nautical Department, Politeknik Ilmu Pelayaran Semarang, 50242, Semarang, Central Java, Indonesia

A.A.Taani is with the Engineering Department, Politeknik Ilmu Pelayaran Semarang, 50242, Semarang, Central Java, Indonesia. conducted on board the MT. ONTARI, a type of product oil tanker owned by PT. Gemilang Bina Lintas Tirta.

In this research is given a variety of data that is descriptive qualitative sourced from respondents, both orally and in writing and related to the object studied. The data comes from the Main Engine's manual book, monthly machine report book, interview with Engineer Officer, and questionnaire distribution.

\section{METHODS OF RESEARCH}

The method of analysis to be used by researchers is using SWOT method SWOT analysis method consisting of Strengths, Weakness, Opportunities, and Threats. From the SWOT understanding will be explained one by one, namely:

a. Strength (Strength), which is any power that has to cylinder liner and piston rings can last long. By knowing the power, cylinder liner and piston ring can survive in working hours according to the manual.

b. Weakness, ie any unfavorable or disadvantageous factors to the engine components, in this case the cylinder liner and piston ring.

c. Opportunities (Opportunities), which are all opportunities that exist and can be used for the condition of the cylinder liner and piston ring to meet normal working hours and work normally.

d. Threats, which can cause losses to the cylinder liner and piston ring, spare parts conditions, spare parts distribution, the level of experience and knowledge of machine officers, and the economic condition of the firm

The analysis on how to solve the impact of oversized cylinder liner on the broken piston ring and surgical parent machine according to SWOT method are as follows: 
TABLE I

INTERNAL AND EXTERNAL FACTORS

\begin{tabular}{rlll}
\hline \multicolumn{1}{c}{ Strengths } & \multicolumn{1}{c}{ Internal Factors } \\
\hline 1 & Cylinder liner tolerance of $0.3-0.8 \%$ & 1 & \multicolumn{1}{c}{ Weakness } \\
\hline 2 & $\begin{array}{l}\text { Unavailability of cylinder liner and piston ring spare parts } \\
\text { Measurement and replacement of piston rings every } 5000 \text { working hours }\end{array}$ & 2 & $\begin{array}{l}\text { The oversized cylinder liner exceeds the allowed tolerance } \\
\text { limit }\end{array}$ \\
3 & $\begin{array}{l}\text { Inspection, measurement, and recondition of cylinder liner every } 8000 \\
\text { working hours. }\end{array}$ & 3 & $\begin{array}{l}\text { Piston rings are often broken due to traffic jams caused by } \\
\text { burning crust }\end{array}$ \\
4 & $\begin{array}{l}\text { Lubrication of cylinder liner according to machine standard and machine } \\
\text { specification. }\end{array}$ & 4 & Stacks of burning mud in scavenging air trunk \\
\hline
\end{tabular}

\begin{tabular}{lll}
\hline \multicolumn{1}{c}{ Opportunities } & \multicolumn{1}{c}{ Threats } \\
\hline $1 \begin{array}{l}\text { Working with agents for spare part distribution of cylinder liner and piston } \\
\text { ring to be quickly received on board. }\end{array}$ & 1 & Short period of in port \\
$2 \begin{array}{l}\text { The use of reconditioned cylinder liners and piston rings while waiting for } \\
\text { new parts. }\end{array}$ & 2 & $\begin{array}{l}\text { Cylinder liner and piston ring spare parts came too late. } \\
\text { Quality spare parts cylinder liner and piston ring not in } \\
\text { accordance with the specifications } \\
\text { The voyage are too short, the weather and the sea } \\
\text { conditions that cause the engine to work heavily. }\end{array}$ \\
3 Thorough inspection and replacement of cylinder liner during docking & $\begin{array}{l}\text { Working with third parties for maintenance of main engines and } \\
\text { turbochargers. }\end{array}$ & 4
\end{tabular}
turbochargers.

score for use in the preparation of questionnaires and

Next the author performs assessment of factors to determine the Factor Weight Factor (WF) to get the score and rating calculation of SWOT settlement strategy matrix using the table as follows:

TABLE II

SWOT MATRIX WEIGHT VALUE

\begin{tabular}{|c|c|c|c|c|c|}
\hline \multicolumn{6}{|c|}{ Internal factors } \\
\hline \multirow{2}{*}{ No } & \multirow{2}{*}{ Strength indicator } & \multicolumn{4}{|c|}{ Handling Urgency } \\
\hline & & 4 & 3 & 2 & 1 \\
\hline 1 & Cylinder liner tolerance of $0.3-0.8 \%$ & 4 & & & \\
\hline 2 & Measurement and replacement of piston rings every 5000 working hours & & 3 & & \\
\hline 3 & Inspection, measurement, and recondition of cylinder liner every 8000 working hours. & & & 2 & \\
\hline 4 & Lubrication of cylinder liner according to machine standard and machine specification. & & & & 1 \\
\hline \multirow{2}{*}{ No } & \multirow{2}{*}{ Weakness indicator } & \multicolumn{4}{|c|}{ Handling Urgency } \\
\hline & & 4 & 3 & 2 & 1 \\
\hline 1 & Unavailability of cylinder liner and piston ring spare parts on board. & -4 & & & \\
\hline 2 & The oversized cylinder liner exceeds the allowed tolerance limit & & -3 & & \\
\hline 3 & Piston rings are often broken due to traffic jams caused by burning crust & & & -2 & \\
\hline 4 & Stacks of burning mud in scavenging air trunk & & & & -1 \\
\hline \multicolumn{6}{|c|}{ External factors } \\
\hline \multirow{2}{*}{ No } & \multirow{2}{*}{ Opportunities indicator } & \multicolumn{4}{|c|}{ Handling Urgency } \\
\hline & & 4 & 3 & 2 & 1 \\
\hline 1 & $\begin{array}{l}\text { Working with agents for spare part distribution of cylinder liner and piston ring to be quickly } \\
\text { received on board. }\end{array}$ & 4 & & & \\
\hline 2 & The use of reconditioned cylinder liners and piston rings while waiting for new parts. & & 3 & & \\
\hline 3 & Thorough inspection and replacement of cylinder liner during docking & & & 2 & \\
\hline 4 & Working with third parties for maintenance of main engine and turbochargers. & & & & 1 \\
\hline \multirow[t]{2}{*}{ No } & \multirow{2}{*}{ Threats indicator } & \multicolumn{4}{|c|}{ Handling Urgency } \\
\hline & & 4 & 3 & 2 & 1 \\
\hline 1 & Short period of in port & -4 & & & \\
\hline 2 & Spare part cylinder liner and piston ring came too late. & & -3 & & \\
\hline 3 & Quality spare parts cylinder liner and piston ring not in accordance with the specifications & & & -2 & \\
\hline 4 & $\begin{array}{l}\text { The voyage are too short, the weather and the sea conditions that cause the engine to work } \\
\text { heavily. }\end{array}$ & & & & -1 \\
\hline
\end{tabular}

Number 1 : Not urgent

Number 2 : Less urgent
Number 3 : Urgent

Number 4 : Very urgent

\section{RESUlts AND Discussion}

The result of strategy formulation using SWOT matrix and calculation result from questionnaire to student officer ATT-II class. 
TABLE III

SWOT MATRIX STRATEGY

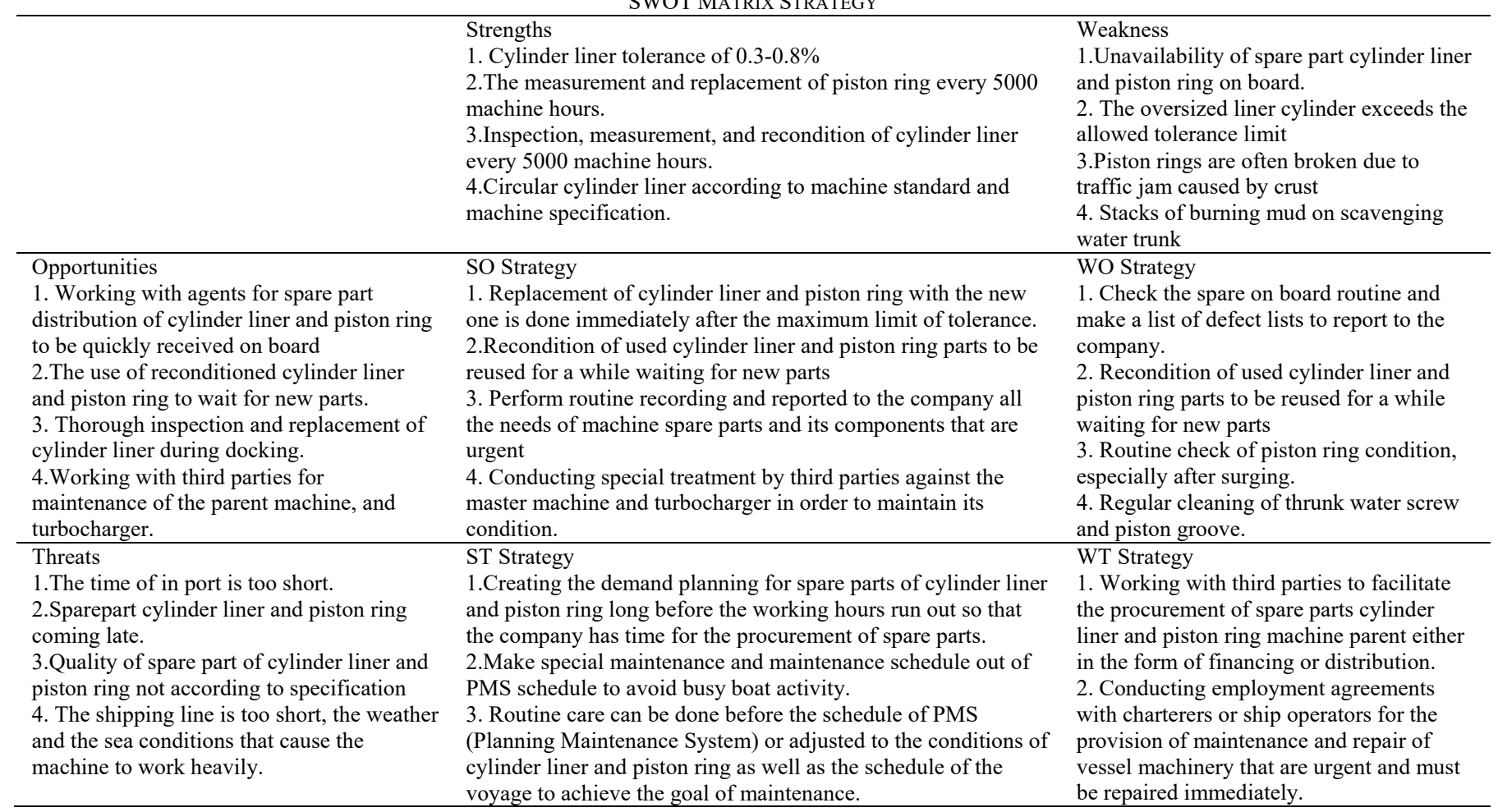

After determining the completion strategy using SWOT problem formulation the author discussed in the previous matrix, the author then distributes the questionnaire to the chapter. The score result can be seen in table below this.

student officer ATT-II as a participant in determining which

strategy is most appropriate to be used as the solution to the

TABLE IV

RESULTS OF SWOT QUESTIONNAIRE RECAPITULATION

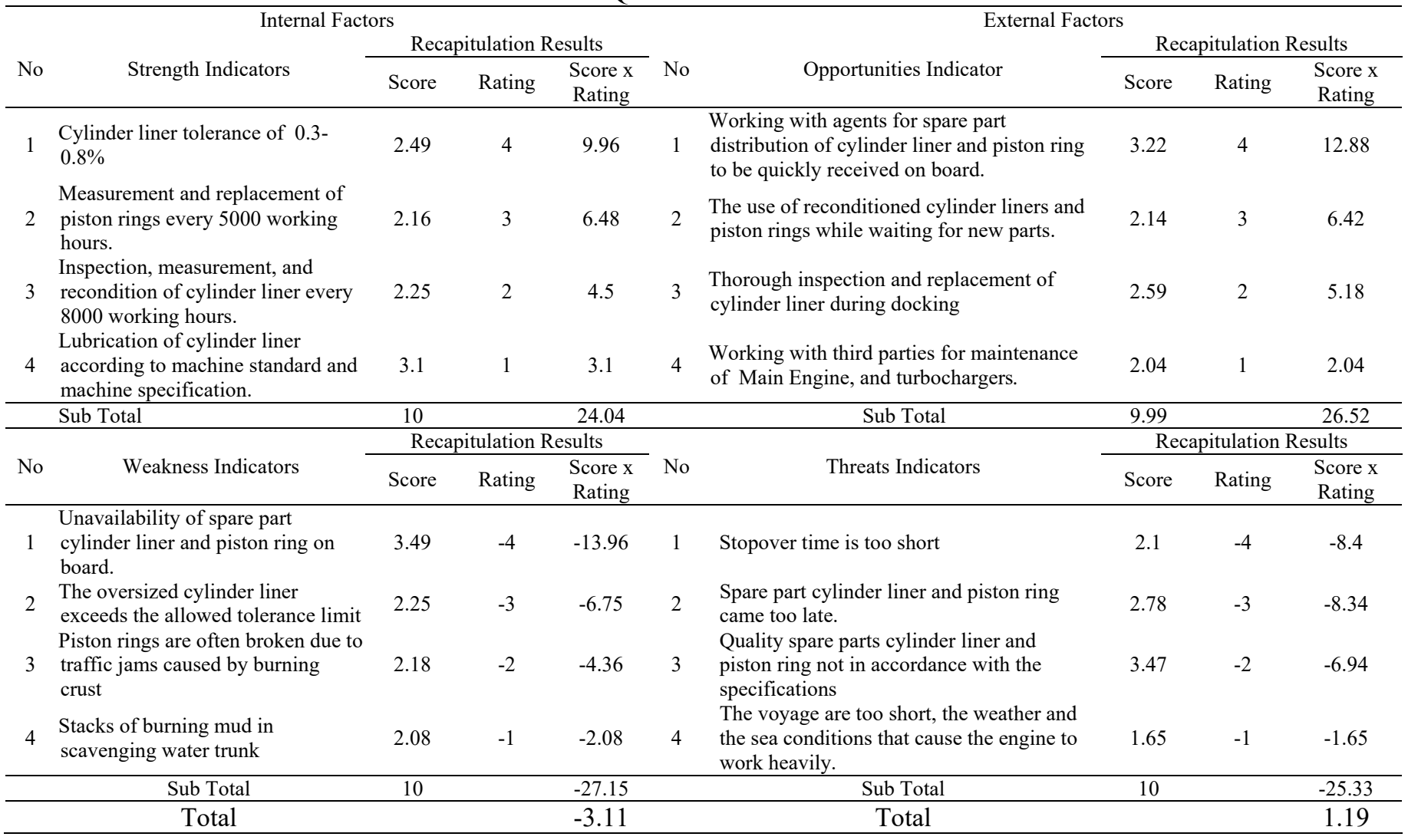


From the results of the assessment of factors that have been compiled in the summary matrix of internal and external factors analysis above, where the value of the score of power $(\mathrm{S})=24.04$ and the value of the score of weakness $(\mathrm{W})=-$ 27.15 then the amount $\mathrm{X})=\mathrm{S}+\mathrm{W}$ then the result $\mathrm{Y}=-3.11$ while the value of the score of odds $(\mathrm{O})=26.52$ and the value of the threat score $(\mathrm{T})=-25.33$ then the result sum $(\mathrm{Y})=\mathrm{O}+$ $\mathrm{T}$ and the result is 1.19 then the point is at $(-3.11 ; 1.19)$ or in quadrant III see the following picture.

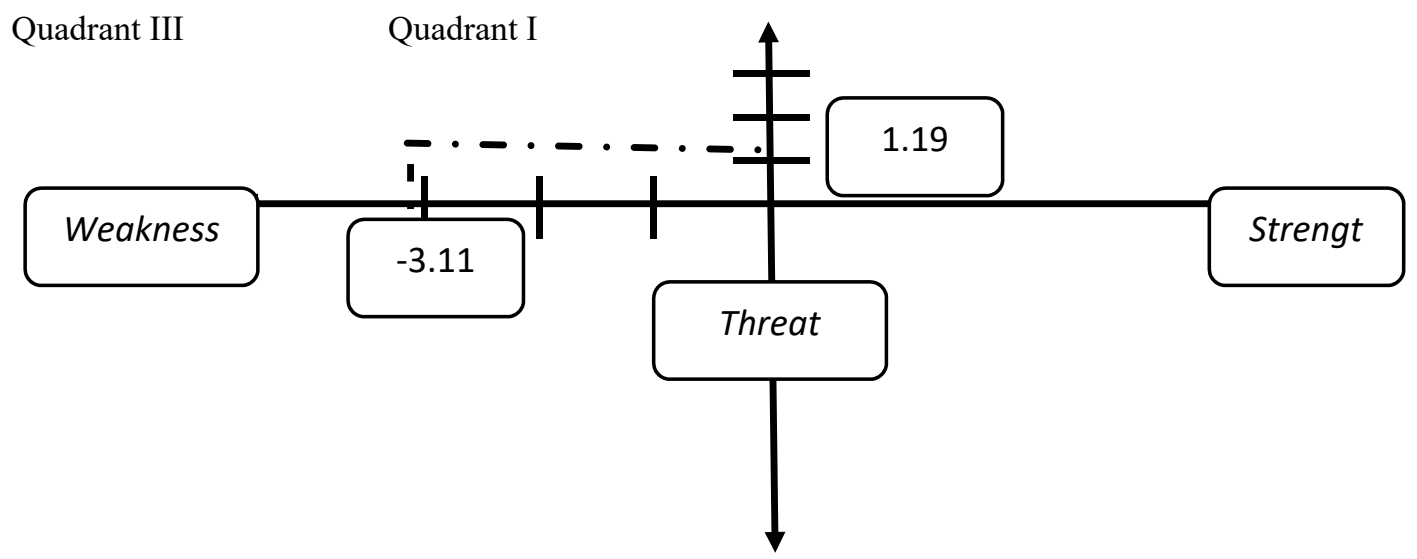

Fig.1. SWOT strategy quadrant map

From the Fig.1 can be seen that the map of the settlement strategy is in quadrant III, then the strategy is to take advantage of opportunities to reduce weaknesses. Based on the results of processing of external and internal factors using SWOT analysis supported by the results of literature study and interview results that the author did with Chief Engineer and $2^{\text {nd }}$ Engineer at the time of the authors carry out marine practices in MT. Ontari, obtained the factor of completion of the weakness factor and opportunity factor that is

a. Check the spare on board routine and create a list of defect lists to report to the company.

b. Recondition of used cylinder liner and piston ring parts to be reused for a while waiting for new parts

c. Routine check of piston ring condition, especially after surging.

d. Regular cleaning of screw water trunk and piston groove.

From the picture it can be seen that the settlement strategy map is in quadrant III, then the strategy is to take advantage of opportunities to reduce weaknesses.

\section{CONCLUSION}

Strategy to minimize the impact of oversized cylinder liner Mains Machine in MT. Ontari is routinely checking spare on board and listing defect list for reporting to company, reconditioning cylinder liner and piston ring parts for reusable spare parts, routine checking of piston ring condition, especially after surgery, regular cleaning of scent water trunk and piston groove.

\section{REFERENCES}

[1] Biberger. Julian, Jurgen Fuber. Hans, "Development of a Test Method for a Realistic, Single Parameter-Dependent Analysis of Piston Ring versus Cylinder Liner Contacts with a Rotational Tribometer," Germany: Tribology International (1-18), 2016.

[2] Jayakumar. N, Mohanamurugan. S, Rajavel, "Study Of Wear In Chrome Plated Cylinder Liner In Two Stroke Marine Diesel Engine Lubricated By Hans Jensen Swirl Injection Principle,” Chennai, India: Materials Today. Vol. 4, pp. 1535-1541, 2014.

[3] Lilly. LRC, "Diesel Engine Reference Book,"Saint Louis, Missouri, USA: Butterworth-Heinemann, 2014.

[4] Mahadi, "Pengaruh Penggunaan Turbocharger dengan Intercooler Terhadap Performansi Motor Bakar Diesel,”Jakarta: Jurnal Dinamis. Vol. 1, No.7:23-28, 2010.

[5] Manual Instruction Book For Maintenance and Component Marine Diesel Engine B\&W Type 6L42MC, of MT.Ontari

[6] Meier-Peter. Hansheinrich., Bernhardt. Frank, "Compendium Marine Engineering," Hamburg: Seehafen Verlag, 2009.

[7] Monthly Report Engine Department Onboard of MT. Ontari, December 2015-January 2017.

[8] Muksin. Subando, "Kajian Pemakaian Bahan Bakar Pada Motor Diesel Generator MAK dI PLTD Gunung Pati Semarang Jawa Tengah," Semarang: Jurnal Teknologi. Vol. 11, No.2:2030-2038, 2014.

[9] Rahmani, R., Rahnejat, H., Fitzsimons, B., and Dowson, D., "The effect of cylinder liner operating temperature on frictional loss and engine emissions in piston ring conjunction," Applied energy, 191, 568-581, 2017.

[10] Rangkuti. Freddy, "SWOT Balanced Scorecard,”Jakarta: PT. Gramedia Pustaka Utama, 2015.

[11] Riduwan, "Dasar-Dasar Statistika," Bandung: CV. Alfabeta, 2007.

[12] Rozhdestvensky. Y, Lazarev. E, Doikin. A., "Effect of the Heat Insulating Coating of the Piston Crown on Characteristics of the "PistonCylinder Liner" Pair,” Russia: Procedia Engineering. Vol. 150, 541546, 2016.

[13] Söderfjäll. Markus, Almqvist. Andreas, Larsson. Roland, "Component Test for Simulation of Piston Ring-Cylinder Liner Friction at Realistic Speeds," Luela, Sweden: Tribology International. Vol. 104, Hal. 57-63, 2016.

[14] Sugiyono, "Metodologi Penelitian Kuantitatif, Kualitatif, dan R\&D," Bandung: CV. Alfabeta, 2007.

[15] Sugiyono, "Metodologi Penelitian Kuantitatif, Kualitatif, dan R\&D," Bandung: CV. Alfabeta, 2016. 
[16] Tjahjono. Tri, "Analisis Keausan Pada Dinding Dilinder Mesin Diesel,”Jakarta: Media Mesin. Vol. 6, No. 2:78-83, 2005.

[17] Wharton. A. J., "Diesel Engine," Manchester: Elsevier's Science \& Technology, 2005.

[18] Woodward. Doug, "Pounder's Marine Diesel Engine and Gas Turbine," Oxford: Elsevier Butterworth-Heinemann 2004.

[19] Zabala. B, Igartua. A, Fernández. X, Priestner. C, Ofner. H, Knaus. O, Abramczuk. M, Tribotte. P, Girot. F, Roman. E, Nevshupa. R., "Friction and Wear of a Piston Ring/Cylinder Liner at The Top Dead Centre Experimental Study and Modelling," Spain: Tribology International, Hal. 1-20, 2016. 